Madrid, Spain

thackerpd@gmail.com Follow Paul D Thacker on Twitter @thackerpd Cite this as: BMJ 2020;371:m4716 http://dx.doi.org/10.1136/bmj.m4716 Published: 09 December 2020

\section{Conflicts of interest among the UK government's covid-19 advisers}

\section{Little is known about the interests of the doctors, scientists, and academics on whose advice the UK government relies to manage the pandemic. Attempts to discover more are frequently thwarted, finds Paul D Thacker}

\section{Paul D Thacker freelance journalist}

As the number of UK deaths caused by covid-19 reached 50000 in early November, England enacted a second national lockdown to control the epidemic. Boris Johnson's government put these measures into action after months of controversial and sometimes confusing policies, including the "rule of six," regional tiered controls, and directions to "stay alert." At the same time, the government has faced mounting questions about procurement decisions, from personal protective equipment to testing kits, from vaccine deals to the services of logistics companies.

Calls for greater transparency around such decisions have included those bodies focused on science and health, such as the Scientific Advisory Group for Emergencies (SAGE), as well as taskforces charged with advising on vaccines and testing. Although Downing Street has become more transparent in disclosing the advice of SAGE, it has kept members' financial conflicts of interest unpublished and shown little concern that advisers to the coronavirus Vaccine Taskforce have financial interests in pharmaceutical companies receiving government contracts. When The BMJ sought further information on these bodies, such as lists of members' interests, the information was denied or requests were unanswered.

\section{Information withheld}

After months of criticism about SAGE secrecy, the government reversed course this summer and began releasing the names of SAGE members, minutes of meetings, and some of its policy papers. Still, the government has refused to release to The BMJ the financial interest forms signed by SAGE members, leaving the public in the dark.

Criticism over SAGE's secrecy first appeared in a Nature editorial ${ }^{1}$ in March. In April, the government's chief scientific adviser Patrick Vallance sent a letter to parliament ${ }^{2}$ stating that SAGE's membership, recommendations, supporting documents, and meeting minutes would be published, but only after the group ceased meeting about covid-19. Vallance argued $^{3}$ that secrecy protected SAGE members and shielded them "from lobbying and other forms of unwanted influence which may hinder their ability to give impartial advice."

Rob Weissman, president of Public Citizen, an American non-profit organisation focusing on government transparency, was troubled by this statement because, he says, corporate interests are always granted access to government decision makers: "It's never a secret from the companies. The secrecy is selective. Secrecy becomes the way to selectively make information available to the powerful, and connected corporations, while the public is kept in the dark."

Within days of Vallance's statement, the Guardian published the names of SAGE members, which included two political advisers to Downing Street, one of whom was the prime minister's now former chief political adviser, Dominic Cummings.

As pressure increased for greater openness, the government finally relented in late May with a pledge for SAGE transparency, publishing dozens of documents, including minutes from the group's first meeting on covid-19 in late January. Reversing his previous statement to parliament, Vallance said, "Openness and transparency around this disease is a social imperative, which is why it's important we don't wait to publish minutes and evidence."

Vallance's decision puts SAGE more in line with recommendations made by the Commons Science and Technology Select Committee in $2011^{4}$ that SAGE membership should not be kept secret. He has, however, ignored the same committee's call to publish SAGE members' declarations of financial interest.

\section{Independence and balance questioned}

Meanwhile, the matter of SAGE's independence persists. "It's not independent," says Martin McKee, professor of European public health at the London School of Hygiene and Tropical Medicine. "It cannot set its own agenda. They can only answer questions the government sends them. They should have more freedom to reshape the questions.” The term "independent," does not appear anywhere in the 64 pages of current guidance ${ }^{5}$ that governs SAGE.

Multiple experts contacted by The BMJ also argued that SAGE appears unbalanced, favouring certain types of scientific proficiency over others. Some claim that SAGE has relied too much on disease modellers who have been given priority over behavioural researchers. Others point out that public health experts, who best understand how to control communicable diseases, should have been given more seats at the table. Meanwhile, it remains tough to confirm if the government is following SAGE's advice.

“They’re not ignoring SAGE,” says Linda Bauld, professor of public health at the University of Edinburgh, who is not a member of the committee, "They're selectively taking their advice." Bauld says that after the government sends questions to SAGE and gets the group's feedback, the government then works in other considerations, such as economics, 
public opinion, and politics. But unlike the advice from SAGE, these other inputs that inform policy are never made public, making it impossible to know if the government has ignored scientific expertise. She adds that SAGE is now more transparent than the Scottish government advisory group, which publishes minutes of its meetings, but which she says contain little information and are not useful.

Like other specialists The BMJ contacted, Bauld also wondered if SAGE requires members to report their financial conflicts of interest. "I've not seen that information published anywhere," she says. The $B M J$ then contacted the Government Office for Science (GOS) to ask whether SAGE members were required to fill in financial disclosure forms. We also requested copies of any such forms for current members. A spokesperson for GOS confirmed that SAGE members must declare their financial conflicts of interest and provided us with an empty template copy of the SAGE disclosure form.

The BMJ is making this form available to the public. ${ }^{6} \mathrm{GOS}$ declined to provide SAGE members' signed disclosures, adding that they are looking at options to make these declarations public while complying with relevant data protection legislation. The $B M J$ is now seeking the financial disclosure forms of SAGE and Vaccine Taskforce members through freedom of information requests.

"Citizens need to be able to trust the advice of professional scientific advisers. We need transparency," says Margaret McCartney, a Scottish general practitioner and former BMJ columnist who has campaigned for financial transparency. "Public trust is paramount and I know there are a huge number of scientists and doctors working extremely hard just now. I don't want those efforts wasted because there hasn't been enough openness."

\section{Interests exposed}

In many cases, the UK government's lack of financial transparency in combating covid-19 has resulted in negative headlines. In April, the government announced ${ }^{7}$ that it was placing Vallance in charge of a new Vaccine Taskforce to expedite research to produce a coronavirus vaccine. Among the named members were AstraZeneca, the Wellcome Trust, and John Bell of Oxford University. The following month, the government announced that Kate Bingham would chair the taskforce, while taking temporary leave from her job as managing partner at SV Health Investors, a life sciences venture capital firm. Bingham is married to the Conservative minister Jesse Norman.

By July the UK government had signed a coronavirus vaccine deal for an undisclosed sum with GlaxoSmithKline, securing 60 million doses of an untested treatment that was still being developed. In September, media outlets reported that Vallance had £6oo ooo (€661 000; \$800 000) worth of shares in the company. The government responded to say that, ${ }^{8}$ while he heads the government's Vaccine Taskforce, Vallance "has no input into contractual and commercial decisions on vaccine procurement, which are taken by ministers following a robust cross government approvals regime."

Days later, the Daily Mail broke another story, this time focusing on Bell. On top of his role with the Vaccine Taskforce, Bell also headed the National Covid Testing Scientific Advisory Panel and chaired the government's new test approvals group. But the Mail discovered something The BMJ had first reported in $2012^{9}$-that Bell had substantial financial interests, now amounting to £773 000 worth of shares, in pharma company Roche, which had sold the government $£ 13.5 \mathrm{~m}$ of antibody tests in May. Following the deal, Bell appeared on Channel 4 News and Radio 4's Today, calling the tests a major step forward. Yet Public Health England found the tests unreliable.

Bell told the Mail that he had no role in the deal and that he had disclosed to the government "a long list of my interests." According to the Mail, "He said that he did not sit on the advisory body involved in the decision to purchase the Roche antibody tests, adding: 'I did not know about the Roche contract until it was signed. I advised on diagnostic home testing kits, not these ones.’”

\section{Disclosure denied}

The BMJ asked the Department for Business, Energy, and Industrial Strategy (BEIS), which announced the Vaccine Taskforce, to confirm that Bell had reported his "long list" of financial interests. We also asked to see any forms Bell had filled in as evidence. Contradicting its own press release which listed Bell as a taskforce member, a BEIS spokesperson told The BMJ, "Sir John Bell is a member of the expert advisory group to the Vaccine Taskforce, rather than a member of the taskforce itself."

The spokesperson added that the expert advisory group is not involved in commercial decision making, and that those involved must declare their conflicts of interest. The spokesperson did not respond to The BMJ's request for copies of Bell's declarations.

The BMJ also approached Oxford University, Bell's employer, to ask for documents that confirm he had disclosed his "long list" of financial interests. Stephen Rouse, Oxford University's head of communications, responded, "Professor Sir John Bell has always declared his financial interests and board membership at Roche, in accordance with the university's conflict of interest policy for all staff." Oxford did not respond to The BMJ's repeated request to see evidence of this disclosure. The $B M J$ is now seeking the financial disclosure form of John Bell through a freedom of information request to Oxford.

\section{Lagging behind the US?}

Much of the transparency The BMJ and others have sought around advisory committees in the UK is automatically provided in the US. "We have strong rules that require transparency, openness of proceedings, and rules in place to deal with conflicts of interest that are automatic," says Rob Weissman, president of Public Citizen, an American non-profit organisation focusing on government transparency.

Not that these rules are impenetrable: Weissman points out that the US vaccine taskforce, called Operation Warp Speed, is being directed by Moncef Slaoui, a former GlaxoSmithKline executive who has been criticised by senators for his pharma investments. The Trump administration bypassed normal government hiring procedures by bringing in Slaoui as an unpaid special adviser, who is therefore not required to disclose his interests. "The arrangement was improper and he should be dismissed immediately because of this conflict," Weissman says. Even if a person is well intentioned, he says, direct financial investments create bias that is impossible for anyone to remove.

\section{Covid cronyism: transparency is "even more important" in a crisis}

In these exceptional times when, for example, contracts are being awarded outside usual procurement rules, it is essential that government decisions are properly documented and made transparent to maintain public trust. So said the National Audit Office ${ }^{10}$ (NAO) earlier this month in its report into government procurement during the covid-19 crisis.

It highlighted "a lack of transparency and adequate documentation" on some key decisions, including how the government identified and managed conflicts of interest. The report said it was "even more important to have a clear approach to managing conflicts of interest when contracts are awarded directly to suppliers without any competition." 
Because so many covid-19 contracts have been awarded to companies with ties to the Conservative Party, the government has faced charges of cronyism.

"You want these things to work," says Peter Geoghegan, a journalist who has been covering the UK's failed covid-19 contracts for Open Democracy, the Guardian, and the London Review of Books. "It's taken a long time for the penny to drop about how this isn't working." Digging up untendered covid-19 contracts involved diligent spade work. Contracts can be published on different websites, which are not easily searchable. Furthermore, the government has been ignoring requirements to publish contracts within 30 days, meaning that it took many months after the pandemic started before the untendered contracts became public. In awarding contracts, a cross government process called the "high priority lane" assessed commercial leads brought in by officials, ministers, MPs, and lords through a special mailbox and which were treated as more credible than leads going through ordinary channels, the NAO reported.

Critics of UK contracting tell The $B M J$ it is impossible to trace the influence of lobbyists in the decisions to award contracts because little lobbying information is published or even collected in the first place. "Considering the gravity of decisions under ministers' consideration, there should be much greater transparency over who's trying to influence them, how, and over what decisions, than is currently the case," says Alex Runswick, senior advocacy manager at Transparency. "We know more about lobbying activity in rural Ireland than we do in Whitehall."

Passed in 2014, Britain's lobbying law requires only rudimentary information to be reported, most importantly, the name of the lobbyist, their company, and address, and the names of clients. In the US, lobbyists must disclose much more information and forms are disclosed quarterly. For each client, lobby companies must disclose the names of their lobbyists; list the matters or specific bills that were lobbied on; who was lobbied, such as a specific congressional committees, government agencies, or White House offices; and how much was spent lobbying, meaning lobbyist salaries and expenses.

"It tells you more than nothing, but not much more," says Weissman of the UK lobby disclosure forms. He says that the US system requires such extensive information, because any one company has broad interests before the government. Pharma companies are considered the most powerful lobby in Washington and they lobby on everything from drug safety to labour laws to healthcare policy, tax matters, contracting law, defence spending, and government subsidies. "You've got no way to assess what they're actually up to," Weissman says of the UK lobbying law.

1 Coronavirus: three things all governments and their science advisers must do now. Nature 2020;579:319-20. doi: 10.1038/d41586-020-00772-4 pmid: 32184490

2 Vallance P. Composition of the Scientific Advisory Group for Emergencies and subgroups informing the government response to covid-19. 4 April 2020. https://publications.parliament.uk/pa/cm5801/cmselect/cmsctech/correspondence/Patrick-Vallance-to-Greg-Clark-reSAGE-composition.pdf.

3 Landler M, Castle S. The secretive group guiding the UK on coronavirus. New York Times. 23 April 2020. www.nytimes.com/2020/04/23/world/europe/uk-coronavirus-sage-secret.html.

4 House of Commons Science and Technology Committee. Scientific advice and evidence in emergencies. February 2011. https:/publications.parliament.uk/pa/cm201011/cmselect/cmsctech/498/498.pdf

5 Cabinet Office. Enhanced SAGE guidance. October 2012. https://assets.publishing.service.gov.uk/government/uploads/system/uploads/attachment_data/file/80087/sage-guidance.pdf.

6 SAGE disclosure form 2020. https://beta.documentcloud.org/documents/20406969-sage-disclosure-form-2020

7 Department for Business, Energy, and Industrial Strategy; Department of Health and Social Care; UK Research and Innovation; Hancock M; Alok S. Government launches Vaccine Taskforce to combat coronavirus. 17 April 2020. www.gov.uk/government/news/government-launches-vaccinetaskforce-to-combat-coronavirus.

8 Ibbetson R. Conflict of interest row as it emerges chief scientific officer Sir Patrick Vallance has $\mathrm{f} 600000$ of shares in vaccine maker contracted to make UK's coronavirus jabs. Daily Mail. 24 September 2020. www.dailymail.co.uk/news/article-8766531/Chief-Scientific-Officer-Sir-PatrickVallance-600-000-shares-vaccine-maker-GSK.html.

9 Thompson MJ, Henegan C. Rapid response to: Open letter to Roche about oseltamivir trial data. December 2012. www.bmj.com/content/345/bmj.e7305/rr/618188.

10 National Audit Office. Investigation into government procurement during the covid-19 pandemic. 18 November 2020. https://collateral.prmax.co.uk/collateral/172733.pdfin.
This article is made freely available for use in accordance with BMI's website terms and conditions for the duration of the covid-19 pandemic or until otherwise determined by BMJ. You may use, download and print the article for any lawful, non-commercial purpose (including text and data mining) provided that all copyright notices and trade marks are retained. 